al-Ihkam: Jurnal Hukum dan Pranata Sosial, 14 (1), 2019: 1-26

ISSN: 1907-591X, E-ISSN: 2442-3084

DOI: http://doi.org/10.19105/al-ihkam.v14i1.1844

\title{
Highlighting Intrinsic Objectives of Bull Race Culture Based on Maqâshid al-Syarî'ah Kaleidoscope
}

\author{
Ainol Yaqin \\ Post-Graduate Universitas Islam Negeri Sunan Ampel Surabaya, \\ Jl. Ahmad Yani 117 Surabaya-60237 \\ Email:ainulfairus@ymail.com \\ Rizka Ahmadi \\ The Australian National University, Canberra ACT 2600, Australia \\ Article history: Received: 7 Agustus 2018, Accepted: 30 Juni 2019, Published: 9 Juli 2019
}

\begin{abstract}
:
This article is to reveal the intrinsic objectives and values of Bull Race culture. Basically, every culture must contain a purpose forecasted by the first initiator. Therefore, it tries to analyze the culture through Islamic Law by using the theories of 'urf and maqâshid al-syariah as the approach. The historical data shows that the intrinsic purpose of the culture is to create prosperity by increasing people's income, especially in crop production. Besides, this culture also gives additional income to the cow's livestock. As the result, Bull Race culture really gives great benefit to the society. The dry field becomes fertile and the crop production gets much more successfull. Furthermore, the income of cow also increases significantly because the local cows are healthy and fat with high quality meat. Meanwhile, the noble values from the Bull Race culture are: hard working, cooperative, competitive, discipline, sportive. Considering the intrinsic objectives and cultural values, it concludes that the culture of Bull Race is not contradictory with the Islamic rules. In fact, it is relevant with the maqasidh al-syari'ah providing that it neither hurts the animals (cows) nor contains gambling and any other immoralities.
\end{abstract}

Keywords:

Bull Race; Culture; 'Urf; Maqâshid al-Syarî'ah

Author correspondence email: ainulfairus@ymail.com Available online at: http://ejournal.iainmadura.ac.id/index.php/alihkam/ Copyright (c) 2019 by al-ihkam. All Right Reserved 


\begin{abstract}
Abstrak:
Artikel ini adalah untuk mengungkap tujuan dan nilai intrinsik budaya kerapan sapi. Pada dasarnya, tiap budaya harus mengandung tujuan yang diramalkan oleh perintis pertama. Artikel ini mencoba menganalisis budaya kerapan sapi dalam Hukum Islam dengan menggunakan pendekatan teori 'urf dan maqâshid al-syarîah. Data historis menunjukkan bahwa tujuan intrinsik budaya kerapan sapi adalah untuk menciptakan kemakmuran dengan meningkatkan pendapatan masyarakat, terutama dalam produksi tanaman. Selain itu, budaya ini juga memberikan penghasilan tambahan untuk ternak sapi. Hasilnya, budaya kerapan sapi telah memberi manfaat besar bagi masyarakat. Lahan kering menjadi subur dan produksi tanaman menjadi jauh lebih sukses. Selain itu, pendapatan dari ternak sapi juga meningkat secara signifikan karena sapi lokal sehat dan gemuk dengan daging berkualitas tinggi. Sementara itu, nilai-nilai luhur dari budaya kerapan sapi adalah: kerja keras, koperasi, kompetitif, disiplin, sportif. Dengan mempertimbangkan tujuan intrinsik dan nilai-nilai budaya, disimpulkan bahwa budaya kerapan sapi tidak bertentangan dengan aturan Islam. Bahkan, relevan dengan maqashid alsyari'ah asalkan tidak menyakiti binatang (sapi) atau mengandung perjudian dan amoralitas lainnya.
\end{abstract}

Kata Kunci:

Kerapan Sapi; Budaya; ‘Urf; Maqâshid al-Syarî'ah

\title{
Introduction
}

The Bull Race is a distinctive and original culture of Madura. ${ }^{1}$ It could not be found in other regions. In the past, Madura people used

${ }^{1}$ Culture is commonly defined as mind and the work of human. Koentjaraningrat, Kebudayaan, Mentalitet dan Pembangunan (Jakarta: Gramedia, 1974), 11. Raymond Williams defines culture into three scopes. First: culture can be used to refer to a general process of intellectual development, spiritual, and aesthetic. Second, culture can be understood as a particular way of life of society, period, and a particular grou Third, culture is also referred as works and intellectual practices, especially artistic activity. John Storey. Translated by Elli el Fajri. Teori Budaya dan Budaya Pop, Memetakan Lanskap Konseptual Cultural Studies (Yogyakarta: Qalam, 2004), 2. The three scopes above illustrate that the cultural sphere has a very broad sense. Meanwhile, 
to hold Bull Race after annual harvest season. The culture that becomes the pride of Madura community cannot be separated from agriculture, especially in terms of plowing and cultivating field using a pair of cows, because the origin of the Bull Race is intended to increase crop production of the society.

Historically, Sultanate of Sumenep in the XV century (1561 AD) was led by a wise king who always cared of his people and assured them to live safely in prosperous condition. He was Syaikh Ahmad Baidhawi, popular with the nickname Katandur Prince, who was enthroned at the Sumenep palace. He was clever in taking lessons from previous kings to make everything perfect. By reason of that, he liked to consult with clever people in achieving the dreams to create sufficient livelihoods so that people could meet their daily needs. At first, he changed the farming methods considering that it was the cause of minimum crop production. The old farming tool, which was stone, was also replaced by tools made from bamboo and pulled by a pair of cows. ${ }^{2}$

It was told that he received a mandate from Sunan Kudus to spread Islam in Madura. To make the mission successfull, in addition to master Islamic teachings, he equipped himself with knowledge on how to grow crops. For this reason, he was given two corn cobs to plant after arriving at the destination. Strangely, after the plant, the corn cobs grew quickly so that it could be harvested in less than two days. Seeing that miracle, many people were amazed and wanted to learn on how to grow the corn. The Prince took this opportunity very much well to preach Islamic teachings in the midst of society. Before he embedded the stick into the field, people were recommended to say, bismillahirrahmarairrah.

They were taught to begin their activities by mentioning the name of the Allah who is Merciful and Blessing. Then, he recommended them to read syahâdataini (two points of Islamic confession) before planting the first seed to the field. The confession is intended to testify that there is no god but Allah Almighty and testify

Peter L. Berger defines culture as the totality of human products, whether material product or not. Peter L. Berger, Langit Suci Agama sebagai Realitas Sosial trans. Hartono. (Jakarta: LP3ES, 1994), 8.

2Edy Setiawan, Menjaga Kesenian Tradisional (Tnp: SIC, 2004), 80; Moh. Noer Dewo, Kerapan Sapi (Jakarta: T. KINTA, 1983), 15. 
that the Prophet Muhammad is His Messengers. ${ }^{3}$ From this, we can understand that the strategy in preaching requires knowledge of the basic needs of the targetted community so that the call to the Islamic path could be well received.

This article aims to analyze intrinsic values and objectives of the Bull Race by tracing the initial history then observing it through a kaleidoscope of maqâshid al-syarî'ah. The focuses of this discussion are the values of Bull Race; the objectives of it; the relationship between the maqâshid al-syarî'ah formulas and the intrinsic objectives of Bull Race culture; and the rules of maqâshid al-syarî'ah as an istinbâth reference of Islamic law in portraying the Bull Race.

\section{The Values of The Bull Race Culture}

The Bull Race or Kerapan Sapi consists of two words; kerapan (race) and sapi (bull), so the Bull Race or Kerapan Sapi simply means the race of bull. There are two versions on the origin of Kerapan Sapi term. The first version stated that it is from the word kerap or kirap which means leaving and being released simultaneously. The second version said that Kerapan Sapi is from Arabic words; gurâbah which means close friendship. However, kerapan does not always use cows or bull to contest. Sometomes, it changes to bufallo as happened in Kangean Island and popular as mamajir. ${ }^{4}$

In a deeper analysis, some noble values of Bull Race could be uncovered and those could also be used as a guide in navigating the community life. These values include:

1. Hard work; this value is reflected in the process of selecting the bull to join the competition. It must be the strong, tough and agile bull and those criteria could be well gained and developed by hard work of the owners. They need to train the bull very well patiently and persistenly. It also needs the strong belief of owners that the bulls can run fast on the race and become the champion.

2. Cooperative; this value is clear from process of the game of race. The Bull Race involves many parties who work hand

\footnotetext{
3Soegianto, Kepercayaan, Magik, dan Tradisi dalam Masyarakat Madura (Jember: Penerbit Kapal Kuda, 2003), 157.

4Tim Penyusun, Ensiklopedi Pamekasan (Yogyakarta: PT Intan Sejati, 2010), 163.
} 
in hand. They are the owners, jockeys, catchers and several other members who actively participate and strive for the victory in the race. Without cooperation, it is impossible to hold this kind of game properly.

3. Competitive; this value can be seen in the process of the race. According to Koentjaningkat, competition is an effort made to outperform or defeat other efforts. In this case, the participants will try as good as possible to make their bulls run faster so they could reach the finish line earlier than other opponents. Conditions like this provoke a competitive mentality among participants.

4. Orderliness; this value is not only obeyed by the contestants, but also the supporters in order to make the race run smoothly. For that reason, participants must be patient in waiting for their turn to race their bulls. Besides, all supporters must obey the rules and are strictly forbidden to do mischief or any damageous and disturbing actions.

5. Sportsmanship; it is reflected in the attitude of the players (jockey) to play fairly, not cheating during the race and be broad minded in the lose. ${ }^{5}$

\section{The Intrinsic Purpose of Bull Race in the Kaleidoscope of Maqâshid al-Syarîah}

Basically, every culture has certain noble goals that each initiator expected to achieve. The Bull Race culture, which was hereditarily spread widely in Madura island until now, is not an exception. At least, there found three kinds of intrinsic objectives of this culture as follow:

\section{a. Increasing Harvest Production}

Earlier, the main livelihoods of the Sumenep people relied on the results of farming. They used very simple agricultural tools which were made of stone. As a result, the field they cultivated was not so fertile so that they failed to make the crop production plentiful. Most of them lived in poor conditions and unable to meet their daily needs

${ }^{5}$ Herry Lisbijanto, Kerapan Sapi (Yogyakarta: Graha Ilmu, 2013), 35; Tim penyusun, Ensiklopedi Pamekasan, 165. 
like foods, clothing, and shelter. Seeing that condition, Syaikh Ahmad Baidhawi (Prince Katandur/1561 AD) sought to find a solution in coping with the less successful crop production. After some discussion, the prince found a brilliant idea to replace a stone-made farming tool with another tool made of bamboo, so that it could be pulled by two (a pair of) cows. The tool is later known as "nanggala" and functions to break up the soil's surface so that the seeds can be easily planted and grow up well. In addition, it is also useful to reduce the farmer's problems in cultivating their agricultural land. ${ }^{6}$

Furthermore, the prince developed the idea creatively and innovatively in order to increase the food production as people expected. Finally, he rediscovered the brilliant idea to attract public attention by arranging a game that in a form of Bull Race. The dry field became the race arena. Meanwhile, a pair of bulls contested in the game must be paired with plows, which are generally used to break up the soil's surface. With the event of the race, the community is expected not to neglect their daily activities as a farmer. It is also wished that the event could trigger enthusiasm and passion for agriculture and farming works. ${ }^{7}$ This idea was very well welcomed and received. That was why, after the harvest, they rehold this celebration enthusiastically.

Moreover, it turned out that the prince's brilliant idea resulted very good responses. Peoples' crops were increasing because the dry fields and rice fields got more fertile since the soils' cavities were widened using a better plowing tool.Additionally, the rainfall got better because of the reforestation in the field which had just been scrubbed. Those all factors made people more enthusiastic about processing and plowing their agricultural land in order to obtain satisfactory yields. ${ }^{8}$ Although the main purpose of the selection is to produce fast running one, the physical health and apperance are also

${ }^{6}$ Edy Setiawan, Menjaga Kesenian Tradisional, 80.

7 Ibid. 81.

${ }^{8}$ Moh. Noer Dewo, Kerapan Sapi, hlm. 24. Madurese in general earn money through livelihoods in the agriculture and livestock sectors, even though the land conditions in Madura are very barren. If the percentage between $70 \%$ and $80 \%$ of the Madurese population meets their needs by relying on agricultural activities. Huub. de Jonge, Madura dalam Empat Zaman: Pedagang, Perkembangan Ekonomi, dan Islam (Jakarta: PT Gramedia, 1989), 35. 
considerable since the factors also affect on producing cattles with good quality meat to eat. Therefore, until now, Maduresse cattle are widely known as that of very soft and delicate meat fibers. ${ }^{9}$

\section{b. Increasing Yield of Cattle}

The Bull Race is also beneficial in terms of increasing the yield of cattle. It is because the more the Bull Race and people enthusiasm are widespread, the more people want to grow the cattle. They would give the best effort to grow the good cattle and make it fat, healthy, and full of good quality meat. This brings the positive effect as the livelihoods of people at the sector of the cattle farming would significantly increase. They become much more enthusiastic in cattle farming particularly at the aim to produce good cows for race or for farming. Moreover, the Madurese cattles are not only attractive or marketable among the domestic buyers, but also from that of overseas.

\section{c. Tightening the Relationship (Silaturrahmi)}

The Bull Race culture held after each harvest can be an inviting magnet in gathering people. They came from various corners of the village to witness this prestigious event. Even, Maduresse who work overseas often went back home to to watch it. This is a moment for them to build and tighten a good relationship (silaturrahmi). They greet, interact and stay in touch each other. Therefore, the bond of kinship is getting closer and stronger among people especially those who live far away. The social relations coming from the Bull Race event is sustainable until now. ${ }^{10}$

Before the Bull Race culture is examined through maqsaâhid alsyarî'ah approach, it is necessary to describe the views of 'ushul figh ulama (Islamic jurists) regarding to this term. The Islamic jurists define maqâshid al-syarî'ah as "the meanings and objectives considered by Islamic laws in all laws or in large part of the laws for seeking the benefit of humanity". Another term of maqâshid al-syarî'ah is al-

\footnotetext{
${ }^{9}$ Moh. Noer Dewo, Kerapan Sapi, 24; Edy Setiawan, Menjaga Kesenian Tradisional, 83.
} ${ }^{10}$ Herry Lisbijanto, Kerapan Sapi (Yogyakarta: Graha Ilmu, 2013), 37. 
asrâr/the secrets behind every law that is ruled.11 Related to this, Imam al-Ghazilî mentioned that mashlahah (public benefits) is principally any action that brings benefits and takes any pernicious things away. However, the last mentioned definition is not theoretically used in this paper. What is meant by mashlahah, in this case, is a protection against the objectives of syara' which consists of five types, namely protecting religion and faith, protecting souls, protecting minds, protecting lineage, and protecting wealth. Therefore, every act containing protection on those five foundations is called mashlahah. On the contrary, every action that injures those five foundations is called mafsadah and every act rejects the mafsadah automatically becomes a mashlahah. ${ }^{12}$

Ushul Figh scholars share the opinion that every syari'ah law must be intended for people benefits, either it is an immediate mashlahah or a mashlahah to realize later on. Sometimes, mashlahah come in the forms of benefits that reject destructive and harmful actions for people. Therefore, every mujtahid (Muslim jurist) must pay attention to maqâshid al-syarî'ah when understanding the divine texts (nash) and formulating the law to make sure the law they produce contains mashlahah for mankind. ${ }^{13}$ Mastery of maqâshid al-syarî'ah for mujtahid is very necessary so that they could avoid misunderstanding

11Wahbah aL-ZuhaYlî, Ushûl al-Fiqh al-Islâmî, Vol. II (Beirut: Dâr al-Fikr, 2009), 307; 'Allâl al-Fâsî, Maqâshid al-Syarî'ah al-Islâmiyah wa Makârimuhâ (Riyadh: Dâr al-gharab al-Islâmî, 1993), 7. According to Ibn 'Asyûr, examining maquașid al-syarî'ah from the universal and specific aspects come into two parts, namely maqâshid al-syarî'ah al'ammâh and maqâshid al-syarî'ah al-khșșâh. The former contains meanings or wisdom considered by syâri' (God) in all or most of the provisions of the shari'ah and not specific to the laws of shari'ah (figh) only. Included in this category are the characteristics of shari'ah, universal goals, wisdom as the center of syara's attention and wisdom in several laws, even if not in the whole law. Meanwhile, the later contains ways that syara' desires in order to maintain useful goals or general benefit for humans in the movements of their actions. Included in this category are every lesson taken into account in the legal observance of human actions and actions, such as the purpose of strengthening guarantees in the rahn contract, enforcement of the household order in the marriage contract, the removal of on-going dharurat in divorce and so on. Muhammad Thâhir Ibn 'Âsyûr, Maqâshid al-Syarî'ah al-Islâmiyah (Yordan: Dâr al-Nafâ is, 2001), 251.

12Muhammad ibn Muhammad al-Ghazâlî, al-Mustashfâ min 'ilmi al-Ushûl, Vol. I (Beirut: Dâr al-Fikr, 2009), 139.

13Wahbah al-Zuhailî, Ushûl al-Fiqh al-Islâmî, Vol. II, 307. 
in revealing the spirit of al- tasyrî' behind verbal nash (texts). This is particularly important when there found a contradiction between or among texts (nash) in which maqsâhid al-syarî'ah can compromise it. This could be done through, among others, choosing and implementing the nash which is more relevant to the mashlahah in a given space and time.

Imam Ash-Syâthibî (an expert of Mâlikî ushul figh) asserted that a mukallaf can reach happiness, pleasure, and blessing both in the world and in the hereafter when the five objectives above are enacted and maintained. Additionally, based on the results of istiqrâ '(induction) on some nash in the Qur' an and hadith, Ushul figh scholars infer that the five basic objectives are the protection of religion, soul, mind, lineage, and wealth. In short, according to Wahbah al-Zuhail's, Islamic law is ordered to preserve the natural system and to protect humanity so there would not be any forms of disobedience. This is through doing actions that reach mashlahah and avoid mafsadat. ${ }^{14}$ Therefore, every human is obligated to care of these five objectives and for the sake of their satisfaction, the law is formulated in the form of orders, prohibitions, and permissions that peopule need to obey and carry them out.

Therefore, in order to maintain and protect these five main objectives, the 'ushul figh scholars divide the maqâshid al-syarî'ah aspects based on the quality of their needs into three levels, namely ad-dharûriyât (primary mashlahah), al-hâjiyât (secondary mashlahah) and at-tahsîniyât (tertiary mashlahah). ${ }^{15}$

14al-Zuhailî, Ushûl al-Fiqh al-Islâmî, Vol. II, 309.

${ }^{15}$ Abû Ishâq al-Syâthibî, al-Muwâfaqât fî Ushûl al-Syarî'ah, Vol. II, (Saudi Arabia: Dâr Ibn 'Affân, 1997), 17; al-Ghazâlî, al-Mustashfâ min 'ilmi al-Ushûl, Vol. I, 139; 'Alî Ibn Muhammad al-Âmidî, al-Ihkâm fî̀ Ushûl al-Ahkâm, Vol. III (Riyadh: Dâr al-Shamî'̂̂, 2003), 343; Muhammad Ibn 'Alî Ibn Âdam Mûsa, al-Jâlis al-Shâlih al-Nâfi' (t.tp: Maktabah Ibn Taimiyyah, 1998), 411; al-Bannânî, Hâsyiyah 'alâ syarhi al-Jalâl al-Mahallî, Vol. II (Beirut: Dâr al-Fikr, t.th), 280; Hasan Ibn Muhammad Ibn Mahmûd al-'Atthâr, Hâsyiyah al-'Atthâr 'alâ Jam'i al-Jawâmi', Vol. II (Beirut: Dâr al-Kutub al-Ilmiah, t.t), 322; Jalâluddîn al-Suyûthî, Syarh al-Kaukab al-Sâthi', Vol. II (Kairo: Maktabah al-Îmân, 2000), 246; Muhammad Ibn Mahmûd Ibn Ahmad al-Bâbartî, al-Rudîd wa al-Nuqûd, Vol. II, (Riyadh: Mahtabah al-Rusy, 2005), 542;'Alî Ibn Sulaimân al-Mardâwî alHanbalî, al-Tahbîr Syarh al-Tahrîr fî̀ Ushûl al-Figh, Vol. VII (Riyadh: Maktabah al-Rusy, 2000), 3379; Muhammad Ibn 'Alî al-Syaukânî, Irsyâd al-Fuhûl ilâ Tahqîq al-Haq min 'Ilmi al-Ushûl, Vol. II (Riyadh: Dâr al-Fadhîlah, 2000), 900; Mahmûd Ibn 
a) ad-dharûriyât is the ultimate benefit concerning with the stability of human life, particularly related to religion and world affairs. The priority scale of this maqâshid level is very high since if it is not maintained, it can cause chaos and disorder of human life as well as damage (fasad) in the world. Also, it perhaps even affects on the disappearance of pleasure, safety, and goodness in the hereafter. Maqâshid in this level includes protection of religion, soul, mind, lineage, and wealth. This is the top level of maqâshid. According to al-Zuhail, the establishment of religion and the world rests on these five things and if maintained, it will result in the stability of both community and personal life of the human. ${ }^{16}$

In carrying out those points of maqâshid, the Islamic law sets three aspects; aspects of îjâd (manifestation/formation), tahqîq (realization) and aspects of baqâ' (eternity). The first aspect is constructive, active and aims to preserve the existence of the five main objectives. Meanwhile, the second aspect comes in the form of negative, passive maintenance and aiming to avoid any nothingness or nonexistence. In the realization of religion, syari'ah obliged all Muslims to uphold five pillars of Islam. Meanwhile, for the sake of preserving religion, it contains jihad, punishment for the destroyer of religion and sentence for apostates. As for the preservation and embodiment of the soul is through the Islamic regulation of marriage which aims to maintain human life with childbirth. Next on, in order to maintain the existence of soul, syara' requires the consumption of

'Abdurrahmân Ibn Ahmad al-Ashfahânî, Bayân al-Mukhtashar Syarh Mukhtashar Ibn alHâjib, Vol. III (Jeddah: Dâr al-Madani, 1987), 118; Muhammad Ibn Muhammad Ibn 'Abdurrahmân, populer dengan sebutan Ibnu Imâm al-Kâmiliyyah, Taisîr al-Wushûl ilâ Minhâj al-Ushûl min al-Ma'qûl wa al-Manqûl, Vol. V, (Kairo: al-Fârûq al-Hadîtsah, 2002), 283; Sulaimân Ibn 'Abdulqawî Ibn 'Abdulkarîm al-Thûfî, Syarh Mukhtashar alRaudhah, Vol. III (Beirut: Mu`assasah al-Risâlah, 1990), 206; Sa'îd al-Din al-Taftâzânî, Syarh Mukhtashar al-Muntahâ al-Ushûlî, Vol. III (Beirut: Dâr al-Kutub al-Ilmiah, 2004), 420; al-Husain Ibn Rayîq al-Mâlikî, Lubâb al-Mahshûl fî 'Ilmi al-Ushûl, Vol. II (t.t. : Dâr al-Buhûts lidirâsah al-Islâmiyah, 2001), 455.

16Wahbah al-Zuhailî, Ushûl al-Fiqh al-Islâmî, Vol. II, 310. 
food and drink as a form of dharuri (basic) needs and also legalizes the punishment of qishas, diyat and kaffarat for the killers. Likewise, syara' also allows human to do everything to develop logical reasoning by absorbing knowledge, technology and art in order to maintain its function to produce many benefits. To protect the logical reasoning ('aql) of human, syara' forbids anything that potentially damage, reduce and weaken it. Besides that, Syara' also regulates wary effect sentences for those who consume khmar and the likes. Likewise, the application of syariah about marriage, the prohibition of adultery and the accusation of zina aim to preserve the progeny, while its objective is to give punishment for zina doer and qadhaf. For the objective of wealth protection to avoid illegal acquisition, theft is forbidden and the thief is automatically punished. Fraud, betrayal, usury and the illegal acquisition of wealth are also forbidden. While syara' requires people to earn fortune and all forms of transactions that do not contradict with syari'ah, this legalization is intended to keep assets in terms of $\hat{\jmath} j \hat{a} d$ and tahqîq.

b) al-Hâjiyât is the type of benefit that human need for ease and elimination of their narrowness, hardship and destitution. The measurement of this level of maqâshid can be known if the thing in this category could not be maintained, although it does not result in damaging the human life system. However, it can lead to narrowness and difficulty in living life. The whole Islamic Syari'ah aims at eliminating narrowness in order to facilitate and lighten humanity in tracing the paths of life. This type of maqâshid is at the second priority after ad-dlarûriyât.

c) al-Tahsîniyât or al-Kamâliyât is the benefits formed by the demands of murû'ah, which is intended to guide good customs and noble ethics. The absence of this category would not suffer the system of human life, nor does it cause narrowness and distress. This kind of maqâshid is not enforced. It just affects on social condition because 
without this type of maqashid, it would be seen as not good enough by common sense.

Based on the description of the maqâshid al-syarî'ah above, the Bull Race culture is in line with maqâshid alsyarî'ah spirit particularly in the dharûriyyât level from îjâd and tahqîq al-mâl. This is closely related to a noble goal of the culture which is to improve the agricultural products of the community, breed quality cows and as hold event for building a relationship. Likewise, it can be categorized into a hâjiyât level because the distinctive culture can relieve the burden on the community to earn a better livelihood in the agricultural sector.

The Principles of Maqâshid al-Syarî'ah as An Absolute Basic of Islamic law Istinbath

To make it easier in making maqâshid al-syarî'ah as the basic of Islamic law istinbath (decision making process), al-Jilâlî al-Marînî formed the principles derived from the reviews of maqâshid al-syarî'ah by Imam asy-Syâthibî. According to him, the maqâshid al-syarîah of Imam asy-Syâthibî could be classified into three categories, namely the rules relating to maqâshid, the rules relatin to mashlahah and mafsadah, and the rules relating to legal reasons of Islamic law.

The first category emphasizes the embodiment of welfare as a vital element of the formulation of Islamic law. The principles included in this section are:

$$
\text { تكاليف الشريعة ترجع الى حفظ مقاصدها في الخلق }
$$

Meaning: Islamic law intends for the welfare of beings

Every maqâshidiyûn agrees that behind every law, there must be a goal to carry on, namely bringing maslahah/benefit and taking away mudharat/mafsadat/danger. They are also in one tone dealing with the division of maqâshid al-syarî'ah into three parts. Imam asy-Syâthibî, for example, said that in sum, the purpose of Islamic law is in three parts, namely ad-dharûriyat, al-hâjiyat and al-tahsîniyat. ${ }^{17}$ In line with asySyâthibî̀', Imam al-Ghazâlî classified the maqâshid al-syarîah in terms of

17asy-Syâthibî, al-Muwâfaqât fî Ushûl al-Syarî'ah, Vol. II, 17. 
the need level and clarity in three types, namely mashlahah in the dharûriyat level, mashlahah in the hâjiyat level and mashlahah in the level of tahsîniyat or tazyinat. 18

Meanwhile, Ibn 'Âsyûr (a Tunisian contemporary Islamic thinker) divided maslahah based on its influence as a pillar of the affairs into three levels:

a) Mashlahah dharûriyât, which is mashlahah in the level of dharurat (basic needs). It needs to carry out this kind of mashlahah for the constellation of human at general because its absence means instability and damaged or destructed human life. The 'destructed' word that Ibnu Âsyûr mentioned does not mean destruction and obliteration, but the condition in which human behave likes animals, which is not preferable and desired by Syâri' (essential Syari'ah maker; Allah SWT and the Messenger). ${ }^{19}$ Included of this maslahah are protection of religion, soul, mind, lineage, and wealth. These five objectives are well considered by all religions for the welfare of human race. al-Ushîl al-khamsah is definitely identified as a goal of syara' not only from one postulate, but also in some postulates. Therefore, it is fair to say that mashlahah ad-dharûriyât is based on the qath' $\hat{\imath}$ postulate at the same level at mutâwatir maknawî.20 This Mashlahah ad-dharûriyât is originally extracted from the 12 nd verse of Surah al-Mumtahanah:

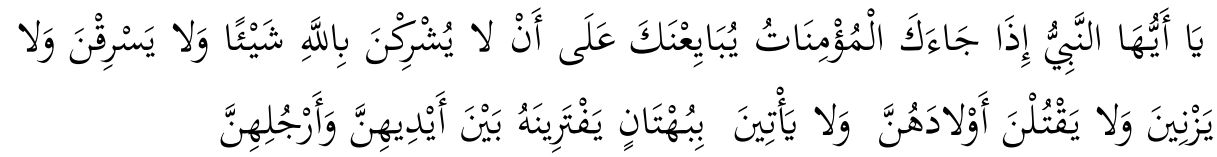

Meaning: "O Prophet, when the believing women come to you pledging to you that they will not associate anything with Allah, nor will they steal, nor will they commit unlawful sexual intercourse, nor will they kill their children, nor will they bring forth a slander they have invented between their arms and legs..."

\footnotetext{
18al-Ghazâlî, al-Mustashfâ min 'ilmi al-Ushûl, Vol. I, 139.

${ }^{19} \mathrm{Ibn}$ 'Âsyûr, Maqâșid al-Syarî’ah al-Islâmiyah, 300.

20al-Ghazâlî, al-Mustashfâ min 'Ilmi al-Ushûl, Vol. I, 418; asy-Syâthibî, al-Muwâfaqât fî̀ Ushûl al-Syarî'ah, Vol. I, 34-39; al-Taftâzânî, Syarh Mukhtashar al-Muntahâa al-Ushûlî, Vol. III, 420.
} 
Relating to this, Imam asy-Syâthibî stated that there are two aspects of protection for mashlahah dharûriyât. First is the establishment of the principles and the main points of the mashlahah and second is the rejection of the causes of anything which could damage them (maslahah). ${ }^{21}$ Meanwhile, for Ibnu Âsyûr, the protection of the mashlahah kulliyât/ dharûriyât aims to keep people in a good condition of the people, and more importantly protection of the people as a whole. Religious protection means keeping the religion safe from anything that possibly damage the faith and all activities relating to the religion itself. This kind of protection, in terms of the people as a whole, means to reject anything that potentially corrupt the definite basis (qath' $\hat{\imath})$ religion.

Meanwhile, the life protection is in the form of maintaining personal spirit and human being as a whole so that they could be safe from any possible damage. According to him, therefore, the punishment of qishash is the weakest step in life protection and therefore ineffective because it can cause other damages. The most important form of life protection, for him, is to keep it safe before any damage comes, such as doing preventive action through fighting infectious diseases. Another form of life protection is protecting the part of body from any damage, especially the punishment such as the full sentence diyat for inadvertently doing criminality.

Later, mind protection is clear from the activities of keeping the human mind safe from damage, chaos and infirmity because if the mind has been contaminated with destructive things, it can result greater damage. As for wealth protection takes the form of preserving human assets from damage or illegally taken. ${ }^{22}$

b) Mashlahah Hâjiyât is the necessity that people need to fulfill to obtain beneficial things, the regularity of their business in a good way. If this could noe be fulfilled, it does not give a bad impact on the existing order. It only causes the situation little bit messier in a disorderness. The example of this is various problems in $m u^{\prime}$ amalah. ${ }^{23}$

${ }^{21}$ asy-Syâthibî, al-Muwâfaqât fî Ushûl al-Syarî'ah, Vol. I, 324-325. See also, Muhammad al-Khudharî Bek, Ushûl al-Figh (Kairo: al-Maktabah al-Tijâriyah al-Kubrâ, 1969), 300. 22Ibn 'Âsyûr, Maquașid al-Syarî'ah al-Islâmiyah, 303.

${ }^{23}$ Ibid., 306. 
c) Mashlahah Tahsiniyât is a mashlahah which completes the life order so that it could guarantee to secure human life and make it elegant in other people' eyes. This factor would be attracting one to invite them get closer to Muslim. Most of maslahah in this type are related to ethical morals or noble values, either it is related to the general things such as closing aurat or special things such as the issue of fithrah (human nature), caring of beards and so on. ${ }^{24}$

Based on the concept of maqâshid al-syarî'ah of Ibnu Âsyûr, the Bull Race culture is suitable with mashlahah dharûriyât (hifdz al-mâl), hâjiyât and tahsîniyât at the same tackle. More specifically, it is in the category of tahsiniyât because it is attractive, artistic and entertaining that it could delight the people and make them relax their nerves and muscles after working for months.

$$
\text { المقاصد الضرورية في الشريعة اصل للحاجية و التحسينية }
$$

Meaning: Maqâshid dharûriyat is the origin of maqâshid hâjiyat and tâhsiniyat. It is also the determination of Islamic law.

This principle is similar to previous one. It means that maqâshid ad-dharûriyat is like the parent of the maqâshids at the level below. It is because the stability and survival of human life closely relate to the maintenance and manifestation of the maqâshid, while the maqâshid alhâjiyat is around the orbit of ad-dharûriyat which serves as a support for the embodiment of the maquashid. The barometer of maqâshid alhâjiyat is to simplify and lighten people in practicing Shari'ah and spending the life time. One example is about the existence of rukhshah (concession) for the sicks not to do fasting until they get recovered. Such provisions can help and maintain religion so that the pillars of Islam (fasting) can still be well enforced. Meanwhile, the maqâshid attahsîniyat serves as a supplement for dharûriyat and hâjiyat. Therefore, ignoring or neglecting this dhâruriyat can result the collapse of hâjiyat and tahsîniyat. However, ignoring hâjiyat and tahsîniyat does not affect to the dharûriyat.

In this case, asy-Syâtibî stated that if tahsîniyat and hâjiyat are broken, chaostic, and injured, it will destroy the dhâruriyat as well. This opinion is based on several following arguments,

24Ibid., 307. 
a. dharûriyat, hâjiyat and tahsîniyat are interrelated, so that the cancellation of the lower level of maqâshid would cause the destruction of the higher maqâshid,

b. tahsîniyah, hâjiyat and dharûriyat are like a sunnah case before a compulsory case,

c. hâjiyat and tahsîniyat accommodation are comparable to dharûriyat. It would be possible to carry out maqâshid dharûriyat if it is well equipped with hâjiyat and tahsinniyat so that mukallaf (persons who are obliged to act in accordance with Allah's orders and to perform worships) can practice Islamic law and live based on their ability and leniency, without any narrowness and distress. Besides that, it is also in line with traditional customs and noble characters.

d. hâjiyat and tahsîniyat function as support for dharûriyat. Thus, paying attention to hâjiyat and tahsiniyat is an urgent action in order to implement the dharûriyat entirely. ${ }^{25}$

$$
\text { المقصد الشرعي من وضع الشريعة اخراج المكلف عن داعية هواه }
$$

Meaning: The purpose of syara' in establishing the law is to save the mukallaf from the lust impulse.

This principle underlies the necessity of Muslims to submit to obedience to the Islamic Shari'a. It is based on several following arguments:

1. Sharîh Nash (clear text) shows the obligation for human being as His servants to worship Allah the Almighty by enliving all His commands and avoiding all His prohibitions. Disobey Islamic rules would cause any damage (mafsadah) as clear from acitivies like blindly following the desire and worshiping other than Allah.

2. Any actions violating Islamic Shari'ah rules must be considered blameworthy. It is very clearly stated in a number of Qur'anic verses about the disgrace of those who blindly follow their desire and stay away from Allah. They are also threatened with painful punishment.

3. Experiments and people customs illustrate that mashlahah concerns the issue of religion. It is also clear that the world

\footnotetext{
25 al-Jilâlî al-Marînî, al-Qawầid al-Ushûliyah 'inda al-Imâm al-Syâthib̂̂ (Kairo: Dâr Ibn
} 'Affân, 2002), 266; asy-Syâthibî, al-Muwâffaqât fî̀ Ushûl al-Syarî'ah, Vol. II, 38. 
will not 'permit' or compromise any bad action solely based on desire. ${ }^{26}$ In this context, the culture initiated by Prince Katandhur did not deviate from the Islamic sharia. In fact, it is consistent with the values and general principles of the Qur'an and al-Sunnah through the noble goals it contains.

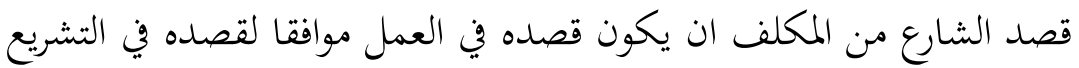

Meaning: The purpose of Syâri 'in determining the law is to make the act of mukallaf in line with the aim of the Islamic shari'ah

The aim of Islamic law is for the benefits of human being. Therefore, they must think of the words and deeds they do whether in line and not violating the aim of syara '.27

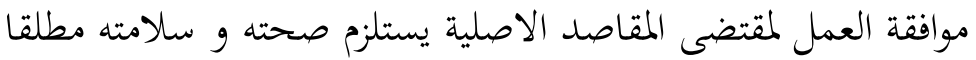

Meaning: Any actions accordance with the purpose of maqâshid alashliyah must be considered valid and absolutely safe.

This principle implied that if the mukallaf have done deeds and spoken in accordance with the maqâshid 'al-ashliyah, individually or collectively, they can be considered legitimate and safe. One example is someone who has performed prayers in accordance with the manner regulated by syara' while aiming it to carry out the divine command, then the prayer is legitimated and sacred (safe from any defect). ${ }^{28}$ Ash-Syâthibî relied this principle based on two basics, namely the purpose of Syâri' 'in giving the law to the mukallaf so their actions are in line with the Islamic Shari'ah, and the purpose of Islamic law is to save the mukallaf from any lust. Thus, every act of mukallaf should be in line with the purpose of maqâshid al- ashliyah and in accordance with the objectives of Syâri ' to save them from any the lust so that they are considered themselves slaves to Allah swt. ${ }^{29}$

The second category concerns about the barometer and the standards for determining mashlahah and mafsadah. The principles included in this category are as follow:

\footnotetext{
26al-Jilâlî al-Marînî, al-Qawầ id al-Ushûliyah 'inda al-Imâm al-Syâthibî, 283; al-Syâthibî, al-Muwâfaqât fî̀ Ushûl al-Syarî'ah, Juz II, 289.

27al-Jilâlî al-Marînî, al-Qawầ id al-Ushûliyah 'inda al-Imâm al-Syâthibî, 265.

28 Ibid., 289.

29al-Syâthibî, al-Muwâfaqât fî̀ Ushûl al-Syarî'ah, Vol. II, 328.
} 


$$
\text { المأخرى لاح المجتلبة شرعا والمفاسد المستدفعة انما تعتبر من حيث تقام الحياة الدنيا للحياة أهواء النفوس في جلب معالمها العادية او درء مفاسدها العادية }
$$

Meaning: Every action with mashlahah or those that reject negative impact (mudharat) can be a consideration of Islamic law as long as it could uphold the worldliness for the sake of the afterlife's prosperity, not solely based on the impulse of lust.

This principle shows that there found a strong connection between the world and the hereafter just like a causality law. A wordly action with welfare becomes media for achieving mashlahah in the hereafter. Therefore, Allah arranges the Islamic rule perfectly so that people could obtain the benefit of the world as well as the hereafter. Therefore, the standard for determining mashlahah and mafsadah must be returned to syara', not just be based on the lust. This is particularly because Islamic shari'a is characterized by a comprehensive orientation to the happiness of life in the world and the hereafter.

Mashlahah and mafsadah that syara' examined are those useful in both enforcing the wordly life and becoming a means of reaching hereafter blessings. Therefore, wordly mashlahah which has no connection to hereafter mashlahah is not considered by Shara', such as those solely coming from the lust. ${ }^{30}$ From here, the Bull Race culture, considering its intrinsic objectives, becomes a means of achieving happiness in the world and the hereafter. When someone has fulfilled their basic needs including clothing, shelter, and food, he/she would no longer be evicted by worldliness and and therefore able to perform individual and social worships very well.

$$
\text { الامر في المصالح مطرد مطلقا في كليات الشريعة و جزئياتا }
$$

Meaning: Mashlahah is absolutely valid in the Islamic Shari'ah whether it is universal and partial

One of the characteristics of Islamic Shari'ah is universality that it could be applied in any place, region, and country from diverse historical background, customs, ethnic, and languages. It also does not specialize any tribe, and/or any group. Apart from that, Islamic

\footnotetext{
30al-Jilâlî al-Marînî, al-Qawầid al-Ushûliyah 'inda al-Imâm al-Syâthibî, 297; al-Syâthibî, al-Muwâfaqât fî Ushûl al-Syarî’ah, Vol. II, 63.
} 
Shari'ah is not limited to certain times or eras. In fact, it is applicable all times. ${ }^{31}$ In short, Islamic Shari'ah is relevant in any place and time. Therefore, the Islamic Shari'a contains universal maqâshid / goals in nature and not confined to a certain place and time. ${ }^{32}$

$$
\text { الطاعة او المعصية تعظم بحسب عظم المصلحة او المفسدة الناشئة عنها }
$$

Meaning: The barometer of obedience or disobedience is on the mashlahah or mafsadah that it causes to appear.

This principle means that the level of either mashlahah and mafsadah is based on the level of either obedience or disobedience it causes to appear. Therefore, mashlahah relating to al-dharûriyat alkhams has the criteria as the greatest mashlahah. On the contrary, every action threatening the main objectives is the biggest mafsadah.

According to Asy-Syâthibî, this principle comes from the existence of threat and hadd/punishment for those who committed to destruct aldharûriyat al-khams, such as doing kufur, murder, adultery, drink khamr and so on. ${ }^{33}$

The third category relates to the classification of laws as $t a^{\prime} a b b u d \hat{\imath}$ and $t a^{\prime} a q q u l \hat{\imath}$. The principless in this segment are as follow:

$$
\text { الأصل في العبادات التعبد و في العادات التعقل }
$$

Meaning: The origin in the worship is ta'abbud (dogmatic), while the problem of culture is rational

Every Islamic law relating to tradition must have 'illat, purpose and wisdom. On the contrary, in term of worship, there is no 'illat and therefore it must be cultural/ dogmatic. Relating to this, asy-Syâthibî mentioned several arguments, those are:

1. Istiqrâ' (induction). Syâri' requires people to take a janabah bath because of release of the semen as well as to break the fasts because intentionally do the release. This apllies although semen is considered holy, different from the dirty (najis). Similarly, it is obligatory to compensate fasting because of menstruation and childbirth and it does not apply the same to compensate prayers for those who get syar'i obstacles. Likewise, this also applies the same for

\footnotetext{
31al-Syâthibî, al-Muwâfaqât fî̀ Ushûl al-Syarî'ah, Vol. II, 86.

32al-Jilâlî al-Marînî, al-Qawầ id al-Ushûliyah 'inda al-Imâm al-Syâthibî, 300.

33al-Jilâlî al-Marînî, al-Qawầ id al-Ushûliyah 'inda al-Imâm al-Syâthibî, 303; al-Syâthibî, al-Muwâfaqât fî̀ Ushûl al-Syarî'ah, Vol. II, 511.
} 
all forms of worship such as fasting, hajj and so forth that people perform merely as of obedience and submission to obey all the commands of Allah and for the sake of His pleasure.

2. The existence of the postulation about the flexibility in worship shows the limited problem. A good example of it is the special rules for travelers to perform qashr or jam' prayers and do ifthâr (not fasting). This dispensation cannot be applied to the muqimin (people who do not travel) even though they feel masyaqqat (get difficulties and exhaustion). ${ }^{34}$ Nevertheless, according to ash-Syâthibi, at global, every worship form intended for the goodness of people at the world and hereafter contains 'illat and wisdom, but not every detail of it is logically reachable.

In line with it, Imam al-Qarâfî (684 H; fiqh expert of Maliki) stated that a mujtahid who formulates the law must first examine the habits widespread in the community so that the law would not eliminate the public benefit. Meanwhile, Imam asy-Syâthibî $(790 \mathrm{H}$; expert of Mâlikî ushûl figh) and Imam Ibn Qayyim al-Jauziyyah (expert of the Hanbalî ushûl fiqh) said that the majority of the fiqh jurists "received" the urf as legal sources as long as there found no postulate or divine text (nash) which explicitly explained the law of a certain problem. Furthermore, Imam Ibn al-Qayyim in his monumental work "I'lâm al-Muwaqqi' în" beautifully described that a mufti (fatwa issuer) and a judge could not release a fatwa and law correctly before comprehending two kinds of things. First is to understand the reality, explore the essence of the phenomenon and observe the indications as well as the surrounding signs. Second is to understand the law of Allah Almighty affirmed in his book (Al-Qur'an) or through the hadith of Messenger then to apply one to another. Anyone who devotes all his abilities for this mission (ijtihad) would get either single or double reward. He also added that those who called by 'âlim is someone who really knows the law of Allah Almighty and His Messenger through knowing and understanding the reality. ${ }^{35}$

${ }^{34}$ DR. al-Jilâlî al-Marînî, al-Qawầid al-Ushûliyah 'inda al-Imâm al-Syâthibî, 307; alSyâthibî, al-Muwâfaqât fî̀ Ushûl al-Syarî'ah, Vol. II, 513.

35Ibnu Qayyim al-Jauziyah, I'lâm al-Muwaqqi'în 'an Rabbil'âlamîn, Vol. I (Riyâd: Dâr Ibn al-Jauzî, 1423 H), 26. 
Concerning with this, Ibn al-Qayyim commented that the right fâqih (figh expert) is someone who is capable to elaborate the formulation of law in connection to reality. In declaring the law, he should not only consider the nash, but also see the social reality so that the the law could accommodate people's welfare (mashlahah). Therefore, he often lowers the ideal level by considering the reality. This is also the reason why Ibn Qayyim told about the necessity to adjust the fatwa due to changes in the times, places, and conditions of society. ${ }^{36}$ In this context, Ibn 'Âbidîn gave graceful description in a risâlah entitled "Nasyr al-'Urfi". He argued that most laws are different each others because of the changes of era and local traditions of people, specifically about something urgent and moral or behavioral decadence. As a consequence, if a certain law remains unchanged in any condition, it must result difficulties and harms (mudharat) then clash with other principles of the Shari'ah about relief and ease as well as the spirit to dismiss all the harmful and destructive things. ${ }^{37}$ Oftentimes, Hanafiyah scholars respond to the diversity of opinions with the follwing expression; "this is the difference in time and place, not in legitimation and argument"38. Therefore, from the perspective of adat or 'urf , Bull Race as the unique culture of Madura is a good adat or 'urf (habit) because it contains a mashlahah (benefit) for the whole community. It deserves, then, preservation and nurture to make still exist and avoid the extinction. However, it is worth to note that Madura's culture should not be corrupted by any acts of immorality and mafsadat.

\footnotetext{
36Ibnu Qayyim al-Jauziyah, I'lâm al-Muwaqqi'în 'an Rabbil'âlamîn, Vol. IV. 139. See also, Ahmad Ibn Idrîs Ibn 'Abdurrahmân al-Shanhâjî, popularly known as imam al-Qarâfi, Kitâb al-Furûq, Vol. III (Cairo: Dâr al-Salâm, 2001), hlm. 977. The principles of fiqh that are consistent with this statement are: لا ينكر تغير الأحكام بتغير الازمان (changes in laws cannot be denied because of the changing times). Ahmad Ibn Muhammad al-Zarqâ, Syarhu al-Qawấ'id al-Fiqhiyah, 2nd edition, (Damasykus: Dâr al-Qalam, 1989), 227.

37Ibnu 'Âbidîn, Majmû'ah Rasâ'il Ibni 'Âbidîn, Vol. II, (s.l: s.a., s.a), 125.

${ }^{38} \mathrm{Ibnu}$ 'Âbidîn, Raddu al-Mukhtâr 'alâ Durri al-Mukhtâr, Vol. IX (Beirut: Dâr al-Kutub al-Ilmiyah. 2003), 178; Muhammad Ibn Abî Sahl al-Sarkhasî, al-Mabsûd, Vol. VIII (Beirut: Dâr al-Ma'rifah, s.a), 178; Ibnu al-Himâm al-Hanafî, Syarh Fath al-Qadîr, Vol. V (Beirut: Dâr al-Kutub al-Ilmiyah, 2003), 405.
} 


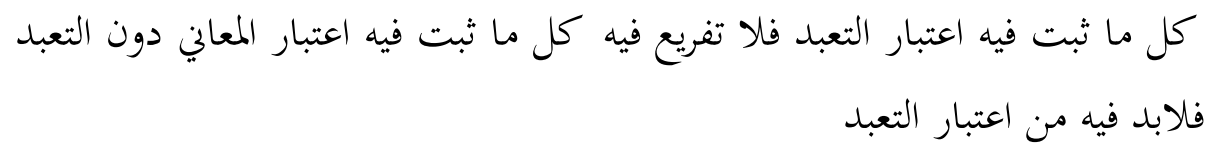

Meaning: Anything dogmatic cannot be seen through qiyâs while everything with meaning must be able to examine through qiyâs

Every legal dogmatic problem can not use analogical inference of qiyâs in determining its law because it cannot be touched by logical reason so that 'illat cannot be established. Meanwhile, every legal problem with unknown 'illat must not be included in the area of qiyâs, such as ruk $\hat{u}^{\prime}$ and sujûd in prayer. Based on this principle, every syarî'ah law must be related to the rights of Allah Almighty or that of His servants either both immediately and later. Allah's right for servants in the realization of self-servitude is by worshiping while not associating Him with anything, carrying out all His commands and avoiding all His prohibitions. Furthermore, performed worldly laws must be shaded by the self-servitude to God. Likewise, every law fulfilling the servants' right, both immediately and later, can only be built on the basis of benefit for the servants themselves. If mashlahah is worldly, it is to ecxamine in the scope of the servants' rights, while if the welfare is afterlife matters (ukhrawi), it is considered as the right of God Almighty. 39

Finally, from this description, we can reveal that the purpose of the Bull Race is in line with maqâshid al-syarî'ah in the field of hifdz almâl (wealth protection) particulary from the aspects of $\hat{\imath} j \hat{a} d$ and tahqîq. Bull Race culture was originally intended by their pioneers to create prosperity through increasing crop yields. Besides that, it is useful to arouse people's enthusiasm to work hard in earning sustenance from livelihoods related to agricultural sector. Furthermore, it share the same 'mission' with maqâshid al-hâjiyât because Madura's culture is projected to facilitate and accelerate the process of breaking up the rice fields so that it would not be so difficult to cultivate. If the Madura's original culture (at the past time) was seen through the

\footnotetext{
39al-Jilâlî al-Marînî, al-Qawầid al-Ushûliyah 'inda al-Imâm al-Syâthib̂̀, 312; al-Syâthibî, al-Muwâfaqât fî Ushûl al-Syarî’ah, Vol. II, 529.
} 
Highlighting Intrinsic Objectives of Bull Race Culture

perspective of 'urf or 'âdat (tradition) concept, 40 it can be considered as a legitimate culture ${ }^{41}$ because it does not clash with the syara' principles as long as it does not contain actions of hurting animals, gambling and all kinds of immorality.

\section{Conclusion}

Bull Race is a unique and autentic culture of Madura that can not be found in other regions. The pioner of this culture was Syaikh

${ }^{40}$ ' $a d a t$ (tradition) is an activity that is done repeatedly without any dependence on reason. Some 'ushûl figh scholars stated that 'urf and 'âdat are synonym, while some others suggested that 'urf is more common than 'âdat because 'urf includes a word and deed, while 'âdat is only an act. On the contrary, other scholars think 'adat is more common than 'urf. Wahbah al-Zuhailî, Usĥul al-Figh al-Islâmî, Vol. II, 105. 3. 'Urf in terms of its validity according to syara' is divided into two types, namely al-urf al-

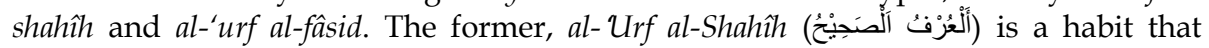
prevails in the midst of society that does not clash with the divine text (nash), does not forbid the lawful and does not justify the forbidden. For example, the halal bihalal tradition, engagement by handing over a variety of cakes and various fruits, the husband living in his wife's house and vice versa and others. Meanwhile, the latter,

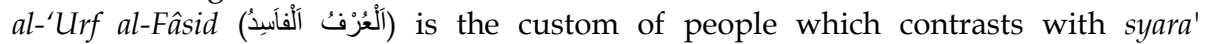
principles, justifying the forbidden or forbidding the lawful. For example, cultural habits in the community in practicing usury, mixing women with men in public locations, drinking alcohol in celebration days, new year celebrations, birthday celebrations, wearing gold-made rings for men, bribery to graduate in a profession or to win the case and so on. al-Zuhailî, al-Wajîz fì Ushûl al-Fiqh, 98; 'Abdu al-Wahhâb Khallâf, Ilmu 'Ushûl al-Figh (Beirut: Dâr al-'Ilmi, 1978), 89; al-Zuhaylî, Ushûl al-Figh alIslâmî, Vol. I, 109.

${ }^{41} \mathrm{Abdu}$ al-Wahhâb Khallâf defines 'urf as everything that has been known and practiced by people be it in the form of a word, an action or leaving a thing. There are two kinds of 'urf, namely 'urf shahîh and 'urf fâsid. 'Urf shahîh is 'urf which has been widely known by the public, not contrary to syara' principles, not justify haram cases and not cancel mandatory cases. Meanwhile, 'urf fâsid is 'urf that has been known to many people yet is contrary to syara', justifying illegitimate matters or canceling compulsory cases. 'Abd al-Wahhâb Khallâf, ' Ilm Ushûl al-Fiqh, 89. In line with it, alZuhaylî gave an understanding of 'urf' as something that has been accustomed to people and they have done, both popular actions among them and a lafadz (word) with special understanding out of common language but could be well understood. 'Urf in this sense includes 'urf amalî and 'urf qaulî. Al-Zuhaylî, Ushûl al-Figh al-Islâmî, Vol. II, 105. Not different from the previous two, Yûsuf al-Qardhâwî formulated the definition of 'urf as everything accustomed and accepted by people in terms of their lives which then proceeds in a sustainable manner, both in the form of a speech and an act, both universal and local. Yûsuf al-Qardhâwî, 'Awâmil al-Si'ah wa al-Murûnah fí al-Syarî'ah al-Islāmiyah (Cairo: Dâr al-Shahwah, 1992), 31.

al-Ihkam: Jurnal Hukum dan Pranata Sosial, 14 (1), 2019: 1-26 
Ahmad Baidawi (Katandur Prince), who had ruled the Sumenep Palace in the XV century $(1561 \mathrm{M})$. This culture was spread out in all region in Madura gradually. Madurese people are very interested in this culture and its annual event always takes so much attention that makes the arena full of visitors. Furthermore. it does not only local people who are interested to watch, but also people from other regions even abroad. The culture which is also the pride of Madura can be examined through kaleidoscope of maqâshid al-syarîah. It is found that this culture is relevant to the maqâshid al-syarîah in the domain of hifdz al-mâl (protection of wealth) particularly from aspects of $\hat{\imath} j \hat{a} d$ and tahqîq. This culture was projected in creating people's prosperity through increasing the livelihoods of the agricultural sector. Besides that, it is also useful to arouse hard work spirit of local people so they would love the jobs they do to earn living blessed by God, especially in the cattle farming. When the cattle market share is increasing, the selling power becomes more expensive and therefore, many people breed cattle with the aim of producing cows for participating in the Bull Race or simply for economic purpose. Therefore, the Bull Race culture is able to preserve as the icon of Madura society as long as it does not contain harmful behaviors like animal torture, gambling and all kinds of immorality.

\section{Bibliography}

'Abd al-Rahmân, Muhammad Ibn Muhammad Ibn. Taisîr al-Wushûl ilâ Minhâj al-Ushûl min al-Ma'qûl wa al-Manqûl. Kairo: al-Fârûq al-Hadîtsah, 2002.

'Âsyûr, Muhammad Thahir Ibn. Maqâșid al-Syarî'ah al-Islâmiyah. Yordan: Dâr al-Nafâ is, 2001.

'Atthâr, Hasan Ibn Muhammad Ibn Mahmûd al-. Hâsyiyah al-'Atthâr 'alâ Jam'i al-Jawâmi'. Beirut: Dâr al-Kutub al-Ilmiah, t.t.

Âmidî, 'Alî Ibn Muhammad al-. al-Ihkâm fî̀ Ushûl al-Ahkâm. Riyadh: Dâr al-Shamî'̂̀, 2003.

Ashfahânî, Mahmûd Ibn 'Abdurrahmân Ibn Ahmad al-. Bayân alMukhtashar Syarh Mukhtashar Ibn al-Hâjib, Juz III. Jeddah: Dâr alMadani, 1987.

Bâbartî, Muhammad Ibn Mahmûd Ibn Ahmad al-. al-Rudûd wa alNuqûd, Juz II. Riyadh: Mahtabah al-Rusy, 2005. 
Bannânî, al-. Hâsyiyah 'alâ syarhi al-Jalâl al-Mahallî. Beirut: Dâr al-Fikr, t.th.

Berger, Peter L. terj. Hartono. Langit Suci Agama Sebagai Realitas Sosial. Jakarta: LP3ES, 1994.

Dewo, Moh. Noer. Kerapan Sapi. Jakarta: P.T. Kinta, 1983.

Fajri, John Storey, terj. Elli el-. Teori Budaya dan Budaya Pop, Memetakan Lanskap Konseptual Cultural Studies. Yogyakarta: Qalam, 2004.

Fâsî, 'Allâl al-. Maqâshid al-Syarî'ah al-Islâmiyah wa Makârimuhâ. Riyadh: Dâr al-gharab al-Islâmî, 1993.

Ghazâlî, Muhammad ibn Muhammad al-. al-Mustashfâ min 'ilmi alUshûl. Beirut: Dâr al-Fikr, 2009.

Hanbalî, 'Alî Ibn Sulaimân al-Mardâwî al-. al-Tahbîr Syarh al-Tahrîr fî Ushûl al-Fiqh. Riyadh: Maktabah al-Rusy, 2000.

Ibnu 'Âbidîn. Majmû'ah Rasâ'il Ibni 'Âbidîn, Juz II. t.tp: t.np, t.t.

Ibnu 'Âbidîn. Raddu al-Mukhtâr 'alâ Durri al-Mukhtâr. Beirut: Dâr alKutub al-Ilmiyah. 2003.

Ibnu al-Himâm al-Hanafî. Syarh Fath al-Qadîr. Beirut: Dâr al-Kutub alIlmiyah, 2003.

Jonge, Huub. de. Madura dalam Empat Zaman: Pedagang, Perkembangan Ekonomi, dan Islam. Jakarta: PT Gramedia, 1989.

Khallâf, 'Abdu al-Wahhâb. 'Ilmu Ushûl al-Figh. Beirut: Dâr al-Ilmi, 1978.

Khudharî Bek, Muhammad al-. Ushûl al-Fiqh. Kairo: al-Maktabah alTijâriyah al-Kubrâ, 1969.

Koentjaraningrat. Kebudayaan, Mentalitet dan Pembangunan. Jakarta: Gramedia, 1974.

Lisbijanto, Herry. Kerapan Sapi. Yogyakarta: Graha Ilmu, 2013.

Mâlikî, al-Husain Ibn Rayîq al-. Lubâb al-Mahshîl fî̀ 'Ilmi al-Ushûl, Juz II. t.t.p.: Dâr al-Buhûts lidirâsah al-Islâmiyah, 2001.

Marînî, DR. al-Jilâlî al-. al-Qawâ'id al-Ushûliyah 'inda al-Imâm alSyâthibî. Kairo: Dâr Ibn 'Affân, 2002.

Muhammad Ibn Abî Sahl al-Sarkhasî. al-Mabsî̀d. Beirut: Dâr alMa'rifah, tt.

Mûsa, Muhammad Ibn 'Alî Ibn Âdam. al-Jâlis al-Shâlih al-Nâfi'. t.tp: Maktabah Ibn Taimiyyah, 1998.

Penyusun, Tim. Ensiklopedi Pamekasan. Yogyakarta: PT Intan Sejati, 2010. 
Qardhâwî, Yûsuf al-. 'Awâmil al-Si'ah wa al-Murûnah fî al-Syarî'ah alIslâmiyah. Kairo: Dâr al-Shahwah, 1992.

Setiawan, Edy. Menjaga kesenian Tradisional. Tnp: SIC, 2004.

Soegianto. Kepercayaan, Magik, dan Tradisi dalam Masyarakat Madura. Jember: Penerbit Kapal Kuda, 2003.

Suyûthî, Jalâluddîn al-. Syarh al-Kaukab al-Sâthi'. Kairo: Maktabah alÎmân, 2000.

Syâthibî, Abû Ishâq al-. al-Muwâfaqât fì Ushûl al-Syarî'ah. Saudi Arabia: Dâr Ibn 'Affân, 1997.

Syawkânî, Muhammad Ibn 'Alî al-. Irsyâd al-Fuhûl ilâa Tahqîq al-Haq min 'Ilmi al-Ushûl. Riyadh: Dâr al-Fadhîlah, 2000.

Taftâzânî, Sa'îd al-Din al-. Syarh Mukhtashar al-Muntahâ al-Ushûlî. Beirut: Dâr al-Kutub al-Ilmiah, 2004.

Thûfî, Sulaimân Ibn 'Abdulqawî Ibn 'Abdulkarîm al-. Syarh Mukhtashar al-Raudhah. Beirut: Mu`assasah al-Risâlah, 1990.

Zuhaylî, Wahbah al-. Ushûl al-Fiqh al-Islâmî. Beirut: Dâr al-Fikr, 2009. 